\title{
Forest fragmentation and its potential implications for the management of the Tarumã-Açu River basin, Central Amazon, Brazil
} Fragmentação florestal e suas potenciais implicações para a gestão da bacia do Tarumã-Açu, Amazônia Central, Brasil

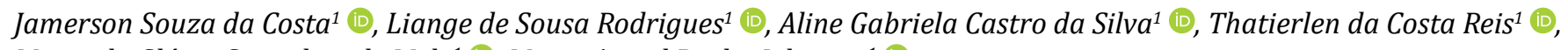
Maria da Glória Gonçalves de Melo ${ }^{1}$ (D), Maria Astrid Rocha Liberato ${ }^{1}$ (D)

\section{A B S T RA C T}

The intensification of deforestation and the consequent fragmentation of the natural landscape in urban and periurban watersheds affect the entire eco-hydrological system, increasing the need to understand how these changes can affect their sustainability. In this sense, the present study evaluated the potential implications of forest fragmentation for the management of the Tarumã-Açu basin, based on the characterization of the structural and functional patterns of the landscape. For this, we mapped and categorized the basin's forest fragments, based on the supervised classification (Bhattacharyya Method) of Landsat/OLI image, and, subsequently, we calculated the landscape metrics (area, density and size, edge, form, core, isolation and connectivity). The metrics showed a very fragmented landscape, especially in the region of the basin's low course, which concentrates the smallest, most dispersed, and vulnerable fragments even in conservation units. The headwater region, on the other hand, has the largest patches, with a large amount of central area and high structural and functional connectivity, which are fundamental for the sustainability of the basin and, therefore, deserve attention and prioritization by managers. The results offer important subsidies and unpublished data that can contribute to elaboration of the basin's management plan and for the definition of conservation and restoration strategies of the forest remnants, indicating priority areas for the implementation of these actions.

Keywords: connectivity; forest; landscape metrics; water resources.

\section{RE S U M 0}

A intensificação do desmatamento e a consequente fragmentação da paisagem natural em bacias hidrográficas urbanas e periurbanas afetam todo o sistema eco-hidrológico, aumentando a necessidade de entendimento de como essas mudanças podem impactar sua sustentabilidade. Nesse sentido, o presente estudo avaliou as potenciais implicações da fragmentação florestal para a gestão da bacia do TarumãAçu, a partir da caracterização dos padrões estruturais e funcionais da paisagem. Para tanto, realizou-se o mapeamento e a categorização dos fragmentos florestais da bacia, a partir da classificação supervisionada (Método Bhattacharyya) de imagem Landsat/OLI, e, posteriormente, o cálculo de métricas da paisagem (área, densidade e tamanho, bordas, forma, área central, isolamento e conectividade). As métricas mostraram uma paisagem bastante fragmentada, especialmente na região do baixo curso da bacia, que concentra os menores, mais dispersos e vulneráveis fragmentos, mesmo em unidades de conservação. Já a região da cabeceira possui os maiores fragmentos, com grande quantidade de área central e alta conectividade estrutural e funcional, fundamentais para a sustentabilidade da bacia e que, portanto, merecem atenção e priorização dos gestores. Os resultados oferecem subsídios importantes e dados inéditos que podem contribuir para a elaboração do plano de gestão da bacia e para a definição de estratégias de conservação e restauração dos remanescentes florestais, indicando áreas prioritárias para implementação dessas ações.

Palavras-chave: conectividade; floresta; métricas de paisagem; recursos hídricos.

\footnotetext{
${ }^{1}$ Universidade do Estado do Amazonas - Manaus (AM), Brazil.
}

Correspondence address: Jamerson Souza da Costa - Conjunto Senador João Bosco Ramos de Lima, 6.000 - Flores - CEP: 69048-040 - Manaus (AM), Brazil. E-mail: jamersonjsc@yahoo.com.br

Conflicts of interest: the authors declare that there are no conflicts of interest.

Funding: none.

Received on: 11/09/2020. Accepted on: 03/18/2021.

https://doi.org/10.5327/Z21769478975

This is an open access article distributed under the terms of the Creative Commons license. 


\section{Introduction}

The Amazon basin accommodates $10-15 \%$ of terrestrial biodiversity and most of the remnants of tropical forests in the world, still constituting an important source of atmospheric moisture, freshwater entering the oceans (approximately 15\%) and carbon storage - 150-200 billion tons (Fearnside, 2016; Nobre et al., 2016). Also, despite the strong dependence of Amazonian populations on regional ecosystems (forests, rivers, wetlands and others), $20 \%$ of forest cover has already been lost, in the last 60 years, due to extensive anthropogenic changes (Nobre et al., 2016; Ruiz-Agudelo et al., 2020), with the highest rates of pantropical deforestation (Numata and Cochrane, 2012).

According to Fearnside (2016) and Ruiz-Agudelo et al. (2020), in the Amazon, deforestation begins with the opening of roads, and from there occurs the occupation (urban or not) and the expansion of the anthropic land uses (extensive agriculture, logging, mining, hydroelectric, exploration of oil and gas, and increased production of biofuels), fragmenting the natural landscape and exerting a serious influence on forest remnants and biodiversity and associated environmental services. According to Nobre et al. (2016), the conversion of forests to anthropogenic uses in this region affects hydrology, climate and biogeochemical flows at different spatial scales.

These changes in the Amazonian land use and land cover are driven by variables and complex political and socioeconomic interactions, which have reduced contiguous forests to smaller fragments ( $<400 \mathrm{ha}$ ), irregular and increasingly isolated (Ruiz-Agudelo et al., 2020). This induces changes in the eco-hydrological dynamics of the landscapes that form the watersheds and puts their sustainability at risk, especially at the local scale (Numata and Cochrane, 2012; Laurance et al., 2018).

Laurance et al. $(2011,2018)$ explain that changes in the structural and functional patterns of the natural landscape of the watershed, with a decrease in the size (area) of forest fragments, have significant deleterious effects on its biophysical dynamics, making it more vulnerable to internal and compromising their resilience. In the case of the Amazon watersheds, due to the distance from the nearest ocean, and, therefore, the greater dependence on the forest evapotranspiration rates themselves, much of this susceptibility derives from the loss of leaf area and the effects to which the fragments edges are subjected (Nobre et al., 2016; Wang et al., 2017). Thus, as fragmentation increases, the impacts on the hydrological regime of the basin are also intensified (Laurance et al., 2018).

According to the studies by Laurance et al. (2011, 2018), desiccation conditions caused by the opening of clearings can penetrate up to $100-200 \mathrm{~m}$ inside the fragments, and lead to great spatiotemporal variations in the flow of fragmented watersheds in the Central Amazon. In fragments of the Eastern Amazon, these desiccant effects can be even more aggressive, and penetrate $1.0-2.7 \mathrm{~km}$ into the forests (Briant et al., 2010), as a result of the advanced state of fragmentation in that region. For Aragón et al. (2015) and Cabral and Costa (2017), a new eco-hydrological cycle begins in each new fragment, increasing the risks of erosion and silting of streams; and all these changes affect not only the local biodiversity, but also the populations dependent on that biota (indigenous and riverine, especially), forcing them to change their livelihoods and traditions.

In general, the fragmentation of the watershed landscape can affect the formation of clouds and lead to an increase in local precipitation in the short term, but a decrease in rainfall rates over time, according to changes in the size and pattern of the patches remaining (Nobre et al., 2016). As pointed out by Laurance et al. $(2011,2018)$, Maeda et al. (2015) and Nobre et al. (2016), the increase in soil surface temperature in watersheds with forest cover loss superior to $20 \%$ alters low-level atmospheric circulation, forming zones of low pressure on clearings, which attract moisture from forested areas and lead to formation of convection clouds. This effect redistributes moisture over deforested areas and affects the recycling of water into the atmosphere, which can lead to the collapse of the hydrological system in the long term (Laurance et al., 2018).

As if the effects of fragmentation were not enough, the occurrence of forest fires (common in the region) hypersatures the atmospheric condensation cores, absorbs solar radiation, promotes atmospheric heating, and also prevents the formation of rain clouds (Sheil, 2018). In periods of drought, when vegetation is already subjected to a certain degree of water stress, forest fragments become more vulnerable. It is precisely in this season that fires happen most frequently (Laurance et al., 2018). Jiménez-Muñoz et al. (2016) suggest that forest fires are the main agents of transition to scenarios of frequent droughts, which should be repeated in the coming decades, as recorded in 2015-2016.

Although many studies propose to assess the potential consequences of forest fragmentation and its relationship with hydrological, structural and functional changes in the largest and most important river basins on the planet, the potential impacts on small Amazon watersheds are still little explored (Maeda et al., 2015), especially in the State of Amazonas. In addition to the complexity of the relationships between the hydrological system and the structural and functional changes of tropical forests, the scarcity of historical data and in part the natural variability of precipitation in these watersheds make this understanding an even greater challenge, besides causing divergences between future possible scenarios (Marengo et al., 2011; Trenberth, 2011; Gloor et al., 2013).

The difficulty of fully understanding this complex and integrated set of natural and anthroponatural formations that characterizes the landscape of urban and periruban watersheds extends to the planning and sustainable management of its natural resources (Rodríguez et al., 2017, 2019). According to Trombeta and Leal (2016), the hydrographic basin as a management unit established by Law $n^{\circ}$ 9,433/97 (Brasil, 1997) requires the elaboration of a water resources plan based on the 
concept of landscape (landscape planning), which allows the proposition of rational strategies for the use and conservation of natural resources, aiming at sustainable development (Trombeta and Leal, 2016; Scholten et al., 2020).

In this sense, Pereira and Cestaro (2016) consider that even the creation of conservation units (CUs) - considered one of the best preservation strategies - tend to suffer the consequences of isolation over time, becoming more susceptible to the effects of edge and adjacent anthropic changes. Thus, the planning and management of watersheds and their resilience capacity must consider network structures (CUs, ecological trampolines and corridors, enrichment of buffer zones, land use planning, and others) and not just the definition of areas unique and isolated (Pereira and Cestaro, 2016).

Considering the variety of eco-hydrological distortions that can permeate fragmented basins, one of the challenges for managers is to identify those aspects of greatest importance and generality (Laurance et al., 2018). This identification can be done through structural (related to physical characteristics) and functional (possibilities of gene flow, individuals and populations) analysis of landscape fragmentation, supported by landscape metrics, increasing the possibilities of efficiency and effectiveness, as they reduce subjectivity in considering conflicts and restrictions (existing and probable) and, consequently, in making decisions (Rudnick et al., 2012).

However, Ruiz-Agudelo et al. (2020) indicate that the management of Amazon watersheds presents yet another obstacle - the institutional and management instruments fragmentation, which have been partially dissociated in the region. The State of Amazonas, for example, reformulated its State Water Resources Policy in 2007, also instituting its management instruments (Amazonas, 2020). However, only two of the nine predicted instruments were implemented: in 2016, the granting of the right to use; and more recently the State Water Resources Plan (Amazonas, 2020).

The State of Amazonas was the first in the North Region of Brazil to create, in 2009, a watershed committee, the Tarumã-Açu River Basin Committee (Amazonas, 2020). However, more than ten years after its creation, the respective basin plan has not yet been implemented. According to Scholten et al. (2020) and Trindade and Scheibe (2019), in addition to the lack of technical, physical and financial support from the States and the difficulty in articulating the various stakeholders, the inefficiency and limitation of the decision-making capacity of committees is due to the lack of basins plans, the main management tool.

This whole context shows that the watershed management plan must be based on the dynamics of occupation, use and anthropogenic alteration of the pre-existing matrix, balancing the prospects for the conservation of water resources and socioeconomic development, increasing the chances of success and reducing negative risks. This requires understanding and anticipating structural and/or functional changes, as well as managing the system's ability to reorganize and recover (Scheffer et al., 2018).
A multifactorial analysis of impacts on the watershed's systemic resilience potential, combining structural and functional connectivity metrics in a Geographic Information System (GIS) environment constitutes, according to Pereira and Cestaro (2016) and Rocha et al. (2018), an important tool to assist managers in decision making, endowing the choices with scientific and methodological rigor. Thus, studies in this sense do not necessarily seek the indication of better and/or worse alternatives for the resilience of socio-ecological systems, but illustrate the potential and/or weaknesses of possible choices (Biggs et al., 2015; Pereira and Cestaro, 2016; Ruiz-Agudelo et al., 2020).

Magnuszewski et al. (2015) ratify that management instruments, such as river basin plans and/or land use planning in traditional ways, do not apply to Amazonian landscapes. It is necessary to understand, with the support of landscape metrics, the changes in structural and functional patterns of forest fragmentation promoted by the complex local biophysical, political and social context, and, with this holistic perspective, proceed to elaborate and implement the management and monitoring plan (Santos et al., 2019).

The construction of basin plans based on the recognition of the spatial-functional interdependence between biophysical components and social well-being makes it possible to design new management arrangements for natural resources, which guarantee the provision of environmental services and which increase the capacity for adaptability and resilience of the remaining natural ecosystems (GarcíaMárquez et al., 2017; Stimson, 2017). In this sense, the present study aimed to evaluate the potential implications of forest fragmentation for the management of the Tarumã-Açu River basin (TARB), based on the characterization of the structural and functional patterns of the landscape.

\section{Materials and Methods}

\section{Study area}

The TARB is located in the central region of the Amazon, on the left bank of the Negro River, upstream of Manaus city; and it constitutes one of the four large watersheds on which the capital of Amazonas was built (Siqueira, 2019). With a total area of 137,273 hectares, it is a fifth-order watershed, morphometrically wide, elongated and few dissected and sinuous, which reduces the risk of flooding, but favors the carrying of sediments and the appearance of erosion processes, mainly in areas without vegetation cover (Costa et al., 2013) (see Figure 1).

According to Antonio (2017), the climate is of the super humid type, according to the De Martonne Index, with three months of mild to moderate drought (July to September) and six months (December to May) of higher humidity and rainfall; June and October are transition months between periods. The mean annual temperature is $27^{\circ} \mathrm{C}$, the mean annual relative humidity is around $80 \%$, and the annual rainfall varies from 1,900 to 3,500 $\mathrm{mm}$ (Costa et al., 2012; Laurance et al., 


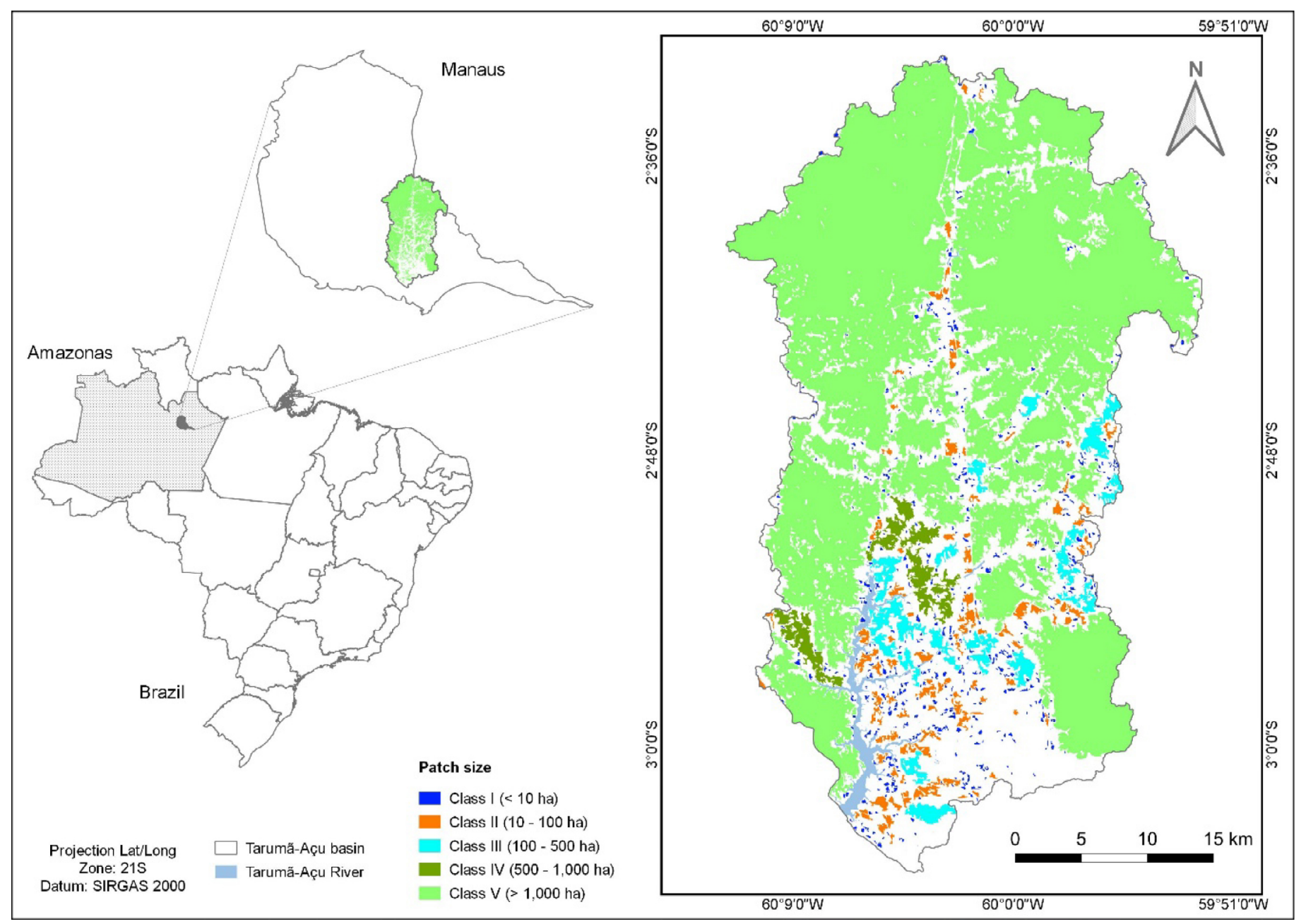

Figure 1 - Location of the Tarumã-Açu River basin with distribution of forest remnants by size class.

2018), which are characteristic of tropical forests. According to Embrapa (2003) and Laurance et al. (2018), the vegetation in the TARB region is predominantly Dense Rainforest, with canopy 30-37 m high and emerging reaching $55 \mathrm{~m}$. There is also an Open Rainforest, Periodically Flooded Alluvial Forest (Igapó Forest), Campinarana and areas of ecological tension (secondary vegetation and agriculture).

Derived from the Alter do Chão Formation, the basin soils are classified as: Yellow Latosol in the plateaus; Red-yellow Podzolic on the slopes; and Hydromorphic soils in the shallows (EMBRAPA, 2003). The sandy-clay textures of the slopes, close to the shallows, and sandy in the shallows also facilitate the occurrence of erosion in areas without vegetation (PROAMBIENTE, 2002). Regarding land use, according to Costa et al. (2012), it is an area of urban and agro-industrial expansion that also has conservation units, agrarian settlement (Tarumã-Mirim) and traditional communities (riverine and Saterê-Mawé Inhambé and Caniço-Rouxinol indigenous peoples).
Structural and functional analysis of the landscape

To generate the forest fragmentation map (primary and secondary forest formations), we used the Landsat 8 OLI sensor image (30 m resolution) of July 27, 2016, made available by the National Institute for Space Research (in Portuguese: Instituto Nacional de Pesquisas Espaciais - INPE). The image selection took into account the absence of cloud and/or shadow coverage over the study area. For image processing, we used the SPRING 5.5.6 software (IBGE, 2013).

In the pre-processing stage, we generated the compositions of the scenes from the spectral bands 4 (red), 5 (near infrared) and 6 (medium infrared), widely used in this type of mapping due to the different spectral responses of the vegetation (Ribeiro et al., 2017). We used the QGIS 3.4.5 software for stacking, clipping and false color composition of the 456/RGB bands. Then, we proceeded to the forest area supervised classification, using the SPRING 5.5.6 software, according to the 
segmentation and classification regions of Bhattacharyya Method, 95\% acceptance (Ribeiro et al., 2017).

According to Oliveira et al. (2015), the planning and management of territorial units based on landscape indexes/metrics requires the interpretation of geostatistical maps, whose quality/accuracy is fundamental for the correct analysis of the spatial pattern and fragmentation indexes. In this sense, as adopted by Rusca et al. (2017), in post-processing, we first verify the accuracy of the classification through the Kappa coefficient ( $\mathrm{K}=0.9861$, calculated by SPRING), categorized by Landis and Koch (1977) as perfect. Subsequently, for classification validation, we resampled the data from georeferenced points distributed along the TARB according to the conditions of accessibility (Jesus et al., 2015). Finally, we vectored and quantified the thematic classes and set the final layout, following the color chart of the Technical Manual for Land Use (IBGE, 2013).
Considering the specificities of fragmentation in the Amazon (Briant et al., 2010; Numata and Cochrane, 2012; Haddad et al., 2015; Sonter et al., 2017; Laurance et al., 2018; Lisboa et al., 2019; Santos et al., 2019; Hansen et al., 2020; Ruiz-Agudelo et al., 2020), we distributed forest patches in five size classes, which were used in landscape analysis: $<10$ ha (Class I), 10-100 ha (Class II), 100-500 ha (Class III), 500-1,000 (Class IV) ha and $>1,000$ ha (Class V), as shown in Figure 1.

Following fragmentation studies in Amazonian environments (e.g. Rusca et al., 2017; Lisboa et al., 2019; Santos et al., 2019; Andrade et al., 2020; Castro et al., 2020; Duarte et al., 2020), we apply the metrics described in Table 1 to characterize the structural and functional patterns of the TARB landscape. The selection included metrics that, according to Baranyi et al. (2011), Saura et al. (2011) and Ziólkowska et al. (2014),

Table 1 - Landscape metrics selected for analysis of forest fragmentation in the Tarumã-Açu River basin.

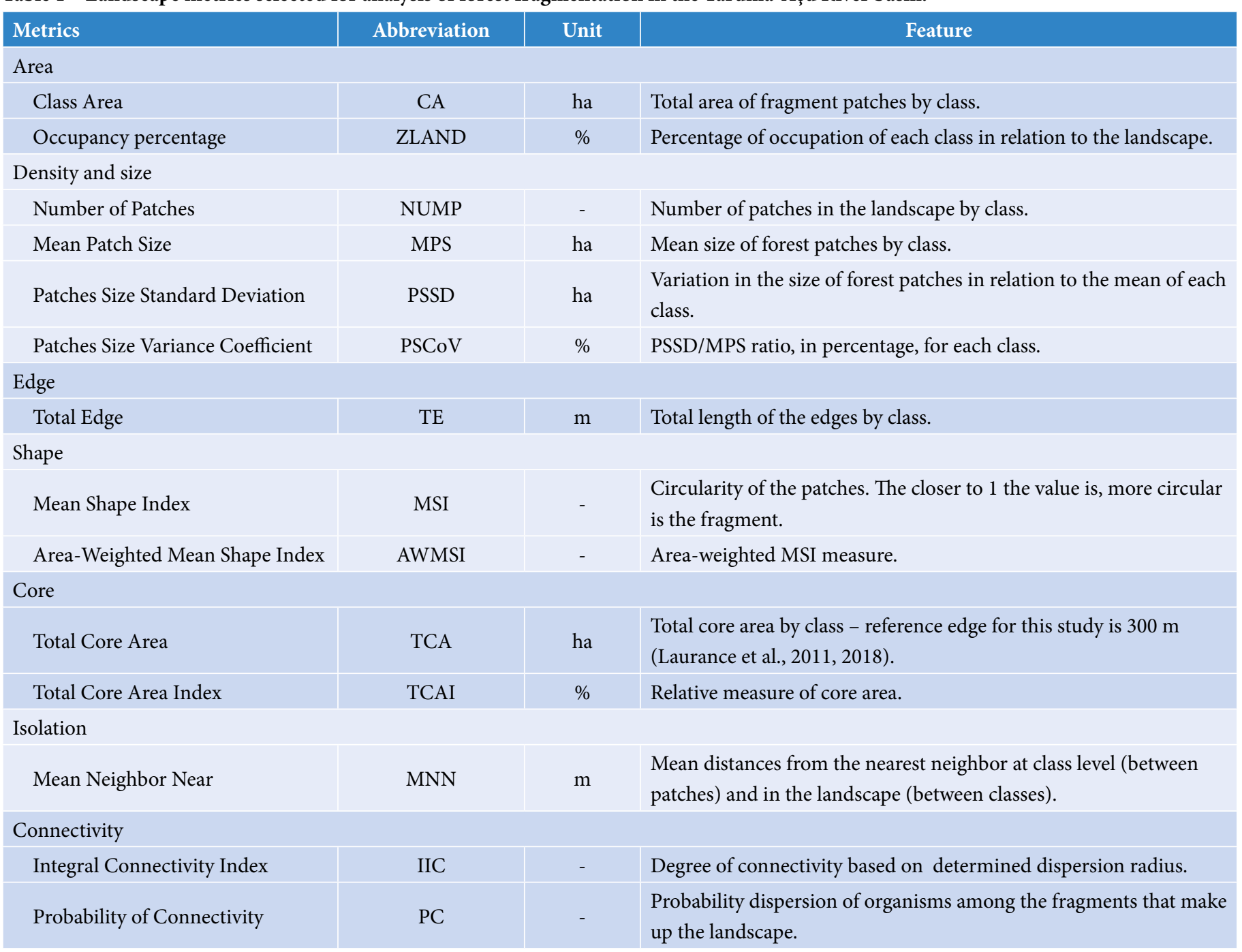

Source: adapted from Jesus et al. (2015) and Thiago et al. (2020). 
present better performance and higher frequency of use in the evaluation of structural and functional aspects of watersheds.

The isolation metric (Mean Neighbor Near (MNN)) measures the inaccessibility of patches to migration from other fragments. Functional indexes (Integral Connectivity Index (IIC) and Probability of Connectivity (PC)), on the other hand, take distances from all possible origins (patches) into account, being good predictors of colonization events, especially in very fragmented landscapes (Ziólkowska et al., 2014). According to Saura et al. (2011), when analyzed together, these indices provide a more complete view of the potential for promoting and/or maintaining connectivity, as they are based on spatial graphs (Graph Theory) and on the concept of measuring habitat availability (accessibility) on the landscape scale.

The Graph Theory considers the fragments as "nodes" and the connections between them as borders, and allows evaluating a network of patches (Gross et al., 2019). For this reason, it is a powerful way of representing complex landscape patterns with advanced performance in the analysis of connectivity (Saura et al., 2011; Ziólkowska et al., 2014). Accessibility measurement integrates the connection resources existing inside the large fragments (intrapatches) with those reachable through strong connections with other fragments in the landscape (interpatches), or the combination of both (Saura and Torné, 2012).

For the structural analysis of forest fragmentation in the TARB, we used the free extensions Patch Grid (raster), for the metrics MNN and Occupancy percentage (ZLAND), and Patch Analyst (shapefile) for the others, both from ArcGIS 10.8 (Andrade et al., 2020). Functional metrics were calculated using the free software Conefor 2.6, designed as a tool to support landscape planning and management through the identification and prioritization of critical locations for ecological connectivity (Saura and Torné, 2012).

Considering the results presented in the studies by Laurance et al. (2011, 2018), which indicate limitations of 100-250 m for the dispersive process of some resident species (Euglossini bees, Scarabaeidae beetles and some birds), we defined $100 \mathrm{~m}$ threshold for quantification of functional connectivity indexes (Rusca et al., 2017). For the PC calculation, we used the 0.05 probability that corresponds to the maximum possibility of dispersion between the nodes, following the one applied by Ziólkowska et al. (2014). The statistical analyzes were processed using the StatSoft Statistica 12.5 software.

\section{Results and Discussion}

The results of the structural metrics of the landscape of the TARB are shown in Table 2. The mapping identified 683 forest fragments distributed in 5 size classes (as shown in Figure 1), which correspond to $66.50 \%$ of the total area of TARB. In the landscape context, the mean patches size (MPS) was $133.66 \mathrm{ha}$, with the smallest fragment measuring around 0.02 ha and the largest $28.092 \mathrm{ha}$, resulting in high standard deviation values (Patches Size Standard Deviation (PSSD)) and variation coefficient (Patches Size Variance Coefficient (PSCoV)). This information suggests that despite being quite fragmented, the basin still has good forest conservation potential, which, according to Oliveira et al. (2015), facilitates the planning and management of conservation and restoration actions.

Most of the remaining forest patches (NUMP $=553$, or $80.97 \%$ ) belong to Class I, whose area is less than 10 ha (Table 2 and Figure $2 \mathrm{~A}$ ). The second most representative class in number of fragments is Class II (10-100 ha), which covers 102 fragments or $14.93 \%$

Table 2 - Landscape metrics by size class of forest fragments in the Tarumã-Açu River basin.

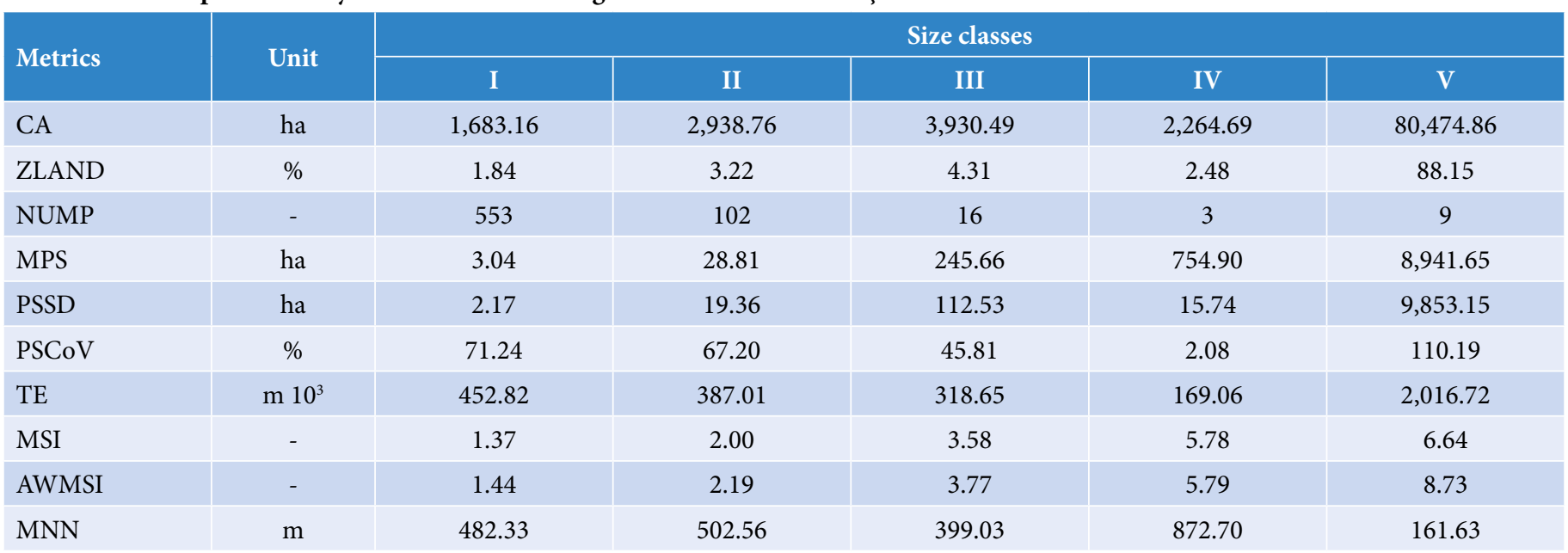

CA: class area; ZLAND: occupancy percentage; NUMP: number of patches; MPS: mean patch size; PSSD: patches size standard deviation; PSCoV: patches size variance coefficient; TE: total edge; MSI: mean shape index; AWMSI: area-weighted mean shape index; MNN: mean neighbour near. 
A

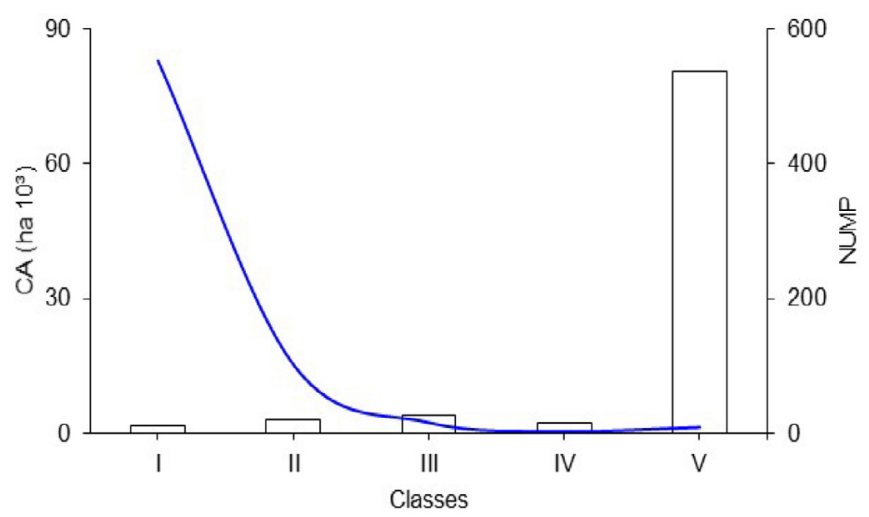

B

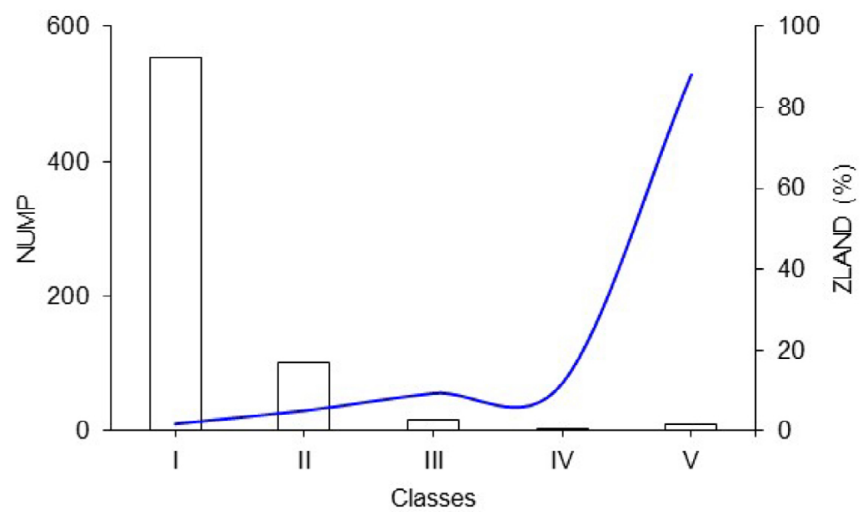

Figure 2 - Number of fragments (NUMP) by size class and total area of forest patches in: (A) hectares - CA; and (B) percentage - ZLAND. NUMP: number of patches; CA: class area; ZLAND: occupancy percentage.

of the total. However, these classes together account for only $5.06 \%$ of all forest vegetation in the TARB (Figure 2B). This diagnosis converges with the studies by Numata and Cochrane (2012), Haddad et al. (2015) and Hansen et al. (2020), whose data showed an increase in the number of fragments $<10$ ha in Amazonian forests, where there is a numerical predominance of patches smaller than 100 ha. Concerning hydrographic basins as a territorial unit, several studies have found similar results, both in the Amazon and in other biomes (Jesus et al., 2015; Rusca et al., 2017; Rex et al., 2018; Lisboa et al., 2019; Andrade et al., 2020; Cavalcante et al., 2020; Castro et al., 2020; Thiago et al., 2020).

Although small fragments generally function as habitat sinks (Odum and Barret, 2008) in very anthropized matrices - is the case of the TARB low basin region - these scattered patches can function as ecological "stepping stones" or connection points, facilitating the flow of some species in the landscape (Saura et al., 2014; Andrade et al., 2020). Managing strategies for these fragments should be considered in watersheds management plans (Castro et al., 2020; Cavalcante et al., 2020; Thiago et al., 2020), aiming at maintaining and/or increasing connectivity with larger fragments. These, in turn, although in smaller numbers (Class V: NUMP $=9$ ), represent $88.15 \%$ of the forest areas (Figure 2B), and function as sources for eco-hydrological processes, standing out in importance for the resilience and sustainability capacity of the watershed landscape (Jesus et al., 2015).

Approximately $70 \%$ of the fragmentation is concentrated in the low basin, the region most affected by anthropogenic uses (urbanization, mining, agribusiness and tourism), even within the limits of conservation units (e.g. Tarumã/Ponta Negra Environmental Protection Area). Duarte et al. (2020) also recorded high rates of deforestation in CUs in the lower Acre River, Western Amazon. These changes in land use and coverage, plus the hyperdinamism of urban and periurban watersheds, increase the vulnerability to sediment transport, and consequently to the occurrence of erosion and silting of stretches of the drainage network (Serrão et al., 2019; Rocha and Lima, 2020).

As Jesus et al. (2015), the reduction of natural landscapes to small patches is related to the economic land use. According to Farias et al. (2018), Laurance et al. (2018), Cavalcante et al. (2020) and Duarte et al. (2020), in Amazonian landscapes, this use is mainly agricultural and often associated with rural settlements, even when overlapping with CUs. This pattern is observed on left bank of the Tarumã-Açu River and close to basin's headwater, where fragmentation is notable into areas corresponding to the Tarumã-Mirim and Santo Antônio settlements, respectively. In the low basin, since it is a periurban watershed, the main factor in transforming the natural landscape was disordered urbanization.

The constructions of highways and opening of roads induces anthropic occupation and transforms the landscape (Gomes et al., 2019). This is very common at TARB, for access to the settled communities and the streams used for non-consumptive purposes of primary contact (balneary). According to Khanna et al. (2017) and Spera et al. (2016), such changes in forest cover impact the variability of precipitation and discharges from river channels, especially in small watersheds. If fragmentation occurs in Permanent Protection Areas (PPAs), susceptibility to erosion and silting of water bodies increases, compromising water quality (Silva et al., 2020).

Regarding the shape, the landscape mean index (Mean Shape Index (MSI)) was 1.61, and, in the division by classes, while Class I presented more circular shapes, the Class $\mathrm{V}$ patches showed more irregular shapes (Figure 3). In the weighted analysis (Area-Weighted Mean Shape Index (AWMSI)) the pattern remained. This concentration of fragments in less complex shapes is evident in the dispersion analysis (Figure 3B). Jesus et al. (2015), Rusca et al. (2017), Rex et al. (2018) and Thiago et al. (2020) found similar results in the shape/area relationship of the fragments when studying urban and periurban basins. 
A

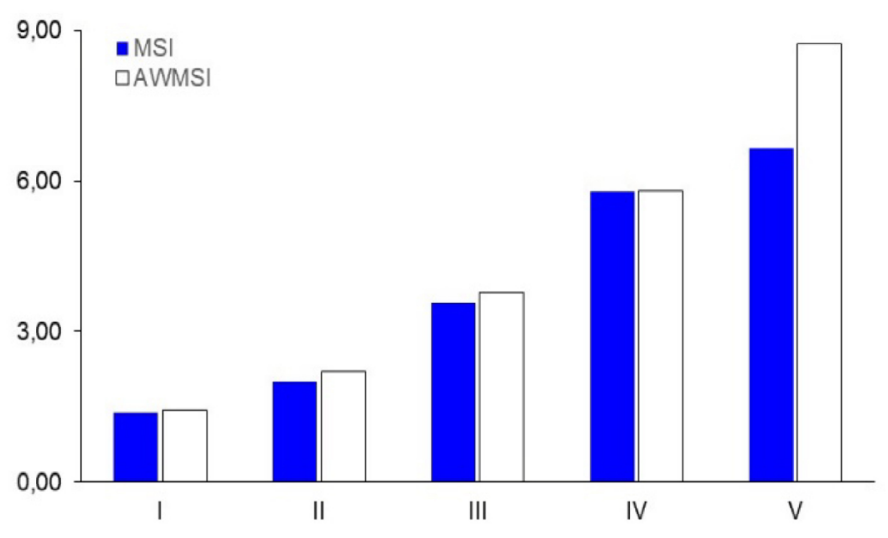

B

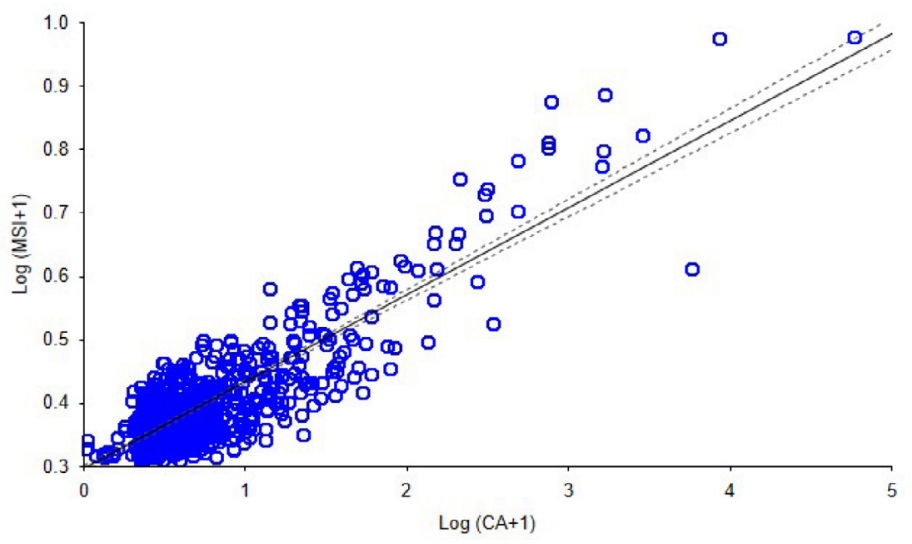

Figure 3 - (A) Circularity indexes (MSI e AWMSI), and (B) dispersion of forest fragments in relation to area (CA) and shape (MSI) values confidence interval 0.95 .

MSI: mean shape index; AWMSI: area-weighted mean shape index; CA: class area.

Fragments with more irregular shapes $(\mathrm{MSI}>2)$ indicate greater border area and smaller core. Thus, in addition to size, shape is another aspect that influences the vulnerability of the patch to different edge effects and other external instabilities (Numata and Cochrane, 2012; Laurance et al., 2018). In this sense, there was a higher total value of edge length (Total Edge (TE)) for the class of the largest fragments. Class IV had the lowest TE, which is justified by the low class area (CA) and ZLAND. The mean edge length at TARB landscape was $668.8510^{3} \mathrm{~m}$.

According to Thiago et al. (2020), the large amount of edge area favors the generalist, predators and invasive parasites species development, which act mainly on the edges of the fragments. Laurance et al. $(2011,2018)$ emphasize that the edge effects are among the most important vectors of temporal-flow changes in fragmented watersheds in the Central Amazon, due to the desiccant effects of clearings on low-level atmospheric circulation, impacting the clouds formation and local precipitation, raising its susceptibility to the vicissitudes of anthropic transformations and fires.

The studies by Laurance et al. $(2011,2018)$ about fragments of Central Amazonia suggest that the edge effects can reach from 10 to $300 \mathrm{~m}$ towards the interior of the patches, and the wider the edge $(>60 \mathrm{~m})$, the greater susceptibility to hydroclimatic alteration effects. For this reason, Lisboa et al. (2019), Cavalcante et al. (2020) and Thiago et al. (2020) are unanimous in considering the core metrics (Total Core Area (TCA) and Total Core Area Index (TCAI)) as measures of habitat quality, since they indicate the effective habitat availability into fragments, that is, where there is no subjection to edge effect.

Thus, Figure 4 expresses the influence of three distinct ranges of the edge over the Tarumã-Açu basin core patches, by size class, weighing the thresholds suggested by Laurance et al. $(2011,2018)$ : minimum width of $10 \mathrm{~m}$ and maximum of $300 \mathrm{~m}$, and an intermediate edge of $150 \mathrm{~m}$. It is observed that even the smallest border width $(10 \mathrm{~m})$ already represents, approximately, $25 \%$ of the Class I fragments total area. However, in this scenario, the TCAI of the basin landscape is still $96.76 \%$. Considering the wider edges ( 150 and $300 \mathrm{~m}$ ), it is possible to verify that the smallest class does not have core area availability, and only $69.74 \%$ and $49.99 \%$ of Class $\mathrm{V}$ is equivalent to the core, respectively. From this perspective, $31.03 \%$ and $50.25 \%$ of TARB's forest areas correspond to edge.

These results are in agreement with the work of Haddad et al. (2015) and Numata and Cochrane (2012), whose analysis of fragmentation in the Amazon found that the forest areas subject to the edge effects were already larger than the total deforested areas, and this proportion has been increasing due to anthropic transformations. Lisboa et al. (2019) and Cavalcante et al. (2020) recorded similar patterns in São Félix do Xingu, Pará, and at the Belém Endemism Center, between the States of Pará and Maranhão, suggesting the worsening of the quality of the remaining patches and the greater fragility of the landscape.

As for the degree of isolation (MNN), the fragments with more than 1,000 ha (Class V) had the shortest average distance from the nearest neighbor $(161.63 \mathrm{~m})$, reinforcing their potential function as maintainers of the watershed's eco-hydrological dynamics. Patches with area 500-1,000 ha (Class IV) have the highest intraclass insulation $(872.70 \mathrm{~m})$. In the TARB landscape assessment, the mean distancing of the fragments was $470.40 \mathrm{~m}$. The registered MNN values suggest, based on Lisboa et al. (2019) and Cavalcante et al. (2020), positive aggregation from the perspective of environmental restoration, and, according to Thiago et al. (2020), confirms the importance of small fragments as connecting elements. 

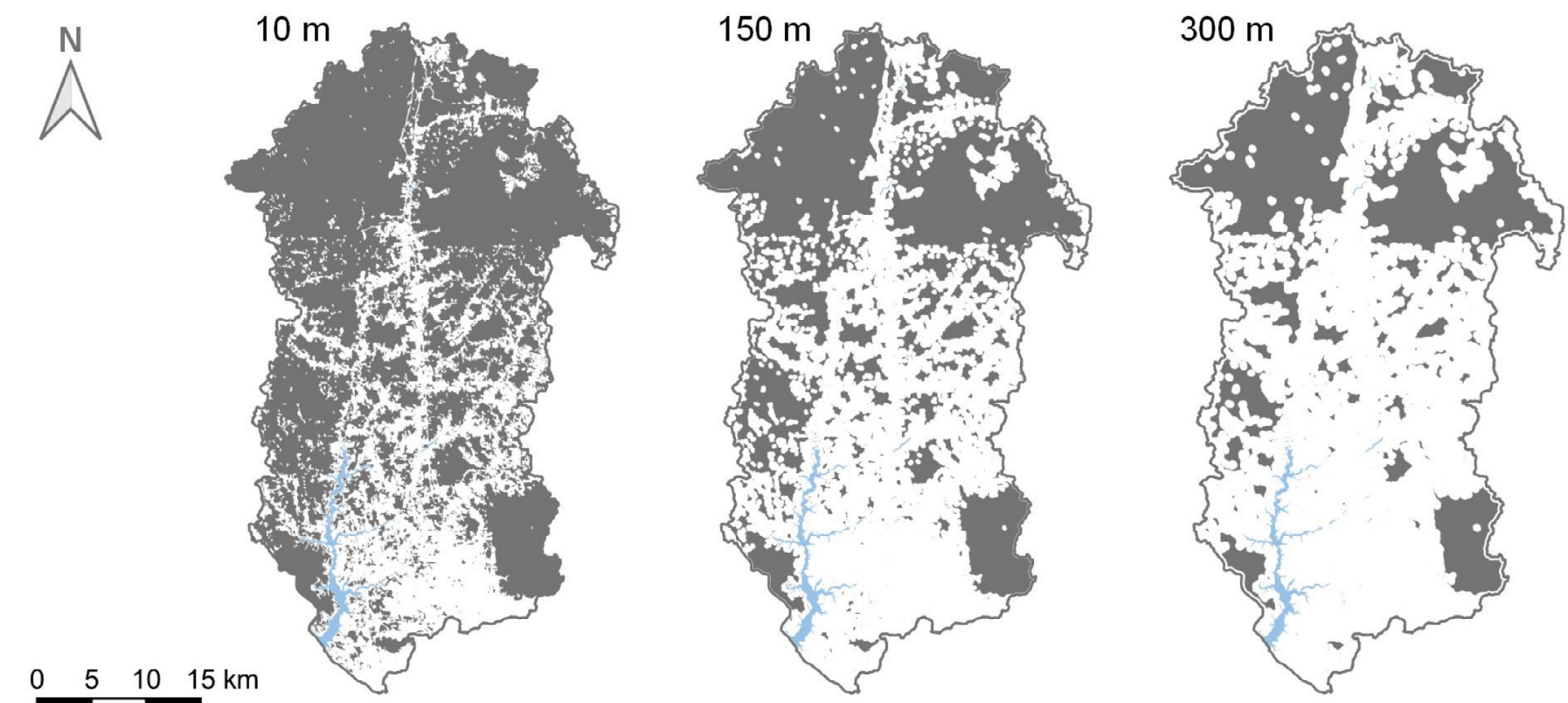

\begin{tabular}{c|ccc|ccc|ccc}
\hline Classes & TCA & TCAI & NUMP & TCA & TCAI & NUMP & TCA & TCAI & NUMP \\
\hline I & $1.250,94$ & 74,33 & 539 & - & - & - & - & - & - \\
II & $2.556,05$ & 86,98 & 102 & 130,52 & 6,01 & 46 & 0,98 & 0,44 & 3 \\
III & $3.612,87$ & 91,88 & 16 & 824,71 & 16,27 & 16 & 137,35 & 5,50 & 9 \\
IV & $2.095,56$ & 92,53 & 3 & 528,76 & 23,55 & 3 & 67,19 & 3,25 & 3 \\
V & $78.443,32$ & 97,63 & 9 & $55.300,54$ & 69,74 & 9 & $39.828,00$ & 49,99 & 9
\end{tabular}

Figure 4 - Comparative simulation between available habitat (core) in hectares (TCA) and percentage (TCAI), and the number of fragments (NUMP) by size class for edges of 10, 150 and $300 \mathrm{~m}$.

TCA: total core area; TCAI: total core area index; NUMP: number of patches.

According to Leite et al. (2013), this positive aggregation derives from the high density of forest fragments, which can facilitate biological flows across the landscape, especially for groups with less mobility (Crouzeilles and Curran, 2016). Radford and Bennett (2007) add that this would increase the structural landscape connectivity, supporting larger populations, but it does not compensate for the reduced extension of available habitats. In other words, it is necessary to think about management strategies that use this aggregation of forest fragments to improve the connectivity of the basin's landscape, increasing matrix permeability. Especially in the low basin, the creation of habitat networks, amalgamation of discrete patches, trampolines, for example, would facilitate mobility and increase recolonization rates, making the fragments smaller nuclei of regeneration (Crouzeilles and Curran, 2016), and potentiating the effects of restoration actions in time and space (Antongiovanni and Metzger, 2005). The benefits can still involve minimizing costs, since the natural process of plant succession could be in charge of reestablishing ecosystem processes (Chazdon et al., 2017).
As indicated by Silva et al. (2020) for the Apeú River basin (Pará), the isolation of TARB fragments was greater in the region where urbanization was consolidated (low basin). It should be noted that an anthropic matrix added to the isolation enhances the fragmentation effects and reduces the resilience capacity of natural patches (Jesus et al., 2015). Thus, watershed management strategies should consider the possibility of increasing size of urban fragments and/or enriching the buffer zones, using fast-growing native forest species, helping to support connectivity (Jesus et al., 2015; Brasil, 2017).

In general, larger fragments were more important for the connectivity of the Tarumã-Açu basin landscape, according to both indexes evaluated - IIC and PC, especially the large patches located in the headwater (Figures 5 and 6). The connectivity indexes were grouped according to the Jenks Optimization Method, also known as "natural breaks", whose principle is to minimize the differences between the values arranged in the same class and to maximize the differences between the classes; in addition to being suitable for application in choropleth maps, its use is standard in GIS (Ramos et al., 2016). 

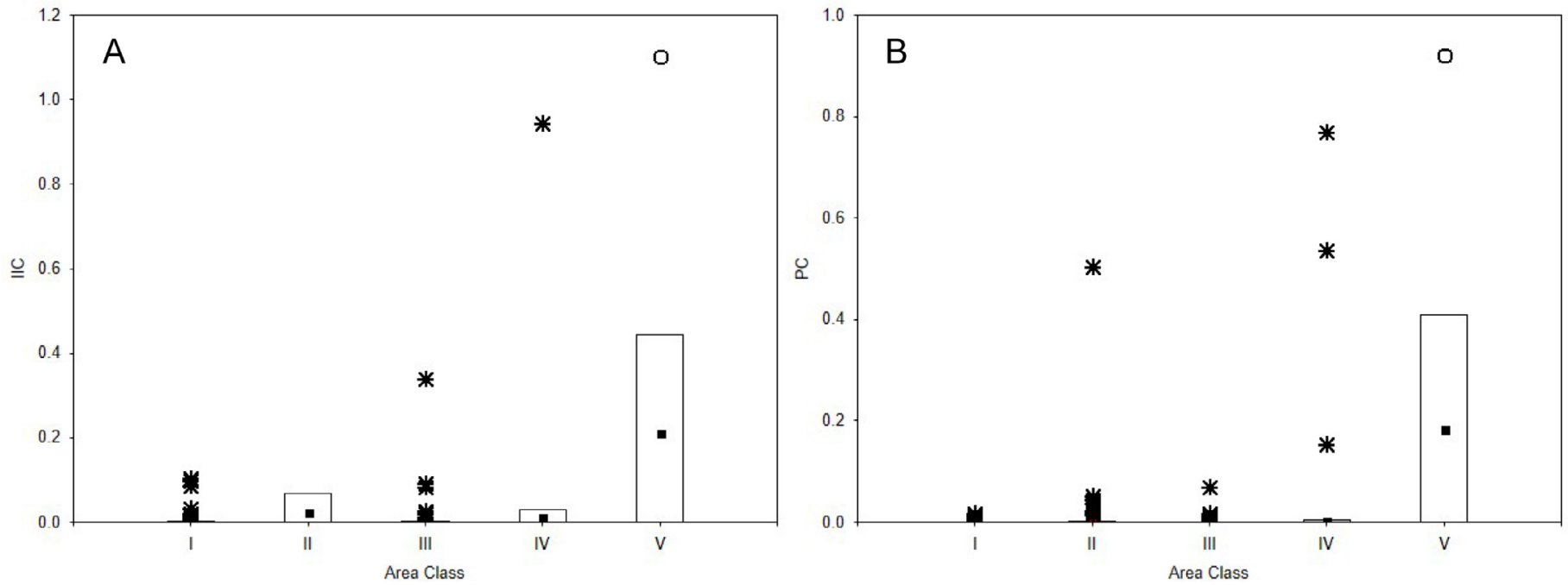

Figure 5 - Variation values of connectivity of the Tarumã-Açu basin fragments (based on $100 \mathrm{~m}$ dispersion threshold) by size class, according to: (A) Integral Connectivity Index; (B) Probability of Connectivity. The columns show the mean and the variation of the indexes, while the asterisks and circles indicate outliers and very discrepant values, respectively.
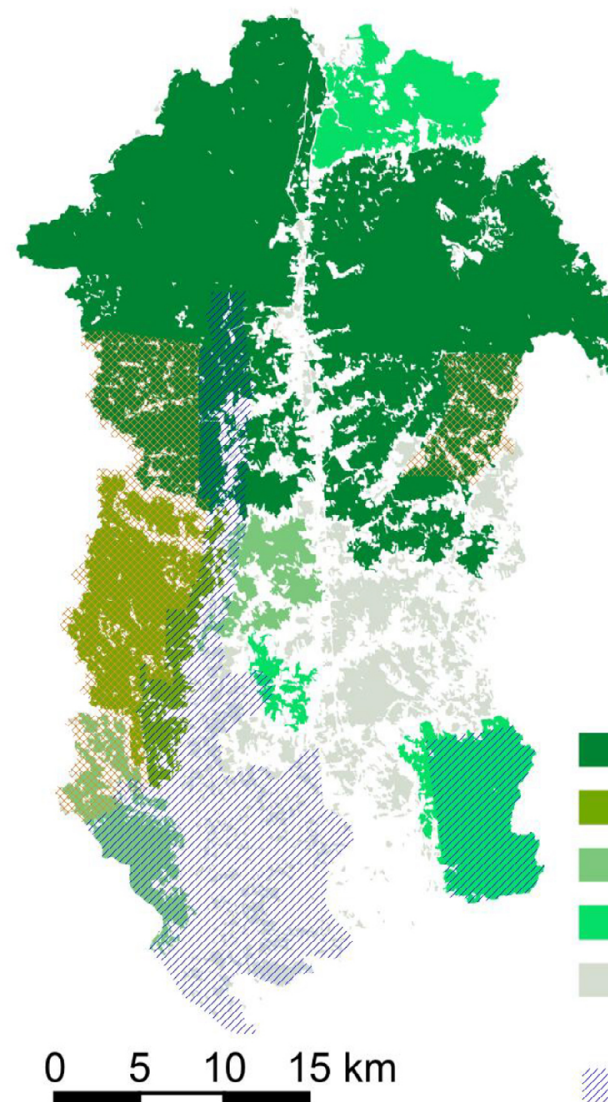

IIC

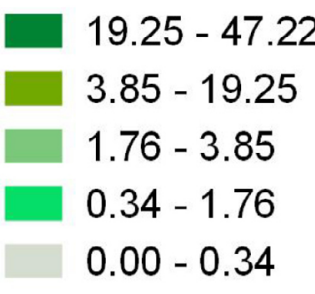

Protected areas

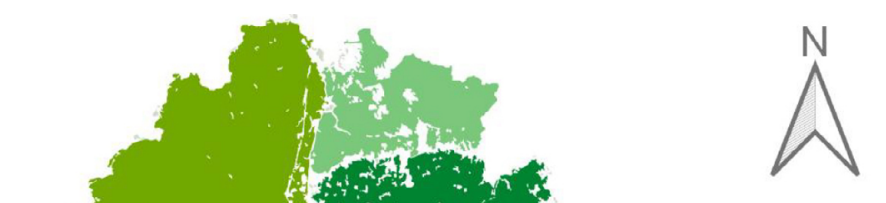

PC

$41.29-48.14$

$2.03-41.29$

$0.92-2.03$

$0.19-0.92$

$0.00-0.19$

Figure 6 - Classification of remaining forest patches in the Tarumã-Açu River basin under $100 \mathrm{~m}$ dispersion threshold, based on the importance for connectivity determined by the Integral Connectivity Index (IIC) and the Probability of Connectivity (PC). 
The results make it evident that most areas with high potential for functional connectivity are outside the limits of the CUs, while those patches with low values of IIC and PC are within protected areas. It is also clear the importance of the Adolpho Ducke Forest Reserve for maintaining connectivity, especially in the low basin. Barber et al. (2014), Castro et al. (2020) and Duarte et al. (2020) warn that protected areas play a fundamental role in the sustainability of the Amazon fragmented landscapes. However, the authors attribute good results to the existence of the respective management plans, and even more to the effectiveness of the inspection actions.

Andrade et al. (2020) and Silva et al. (2020) underscore the importance of connectivity as a way of promoting key ecosystem services for water and soil conservation in watersheds. Therefore, the planning and management of conservation and recovery strategies for connectivity in small basins, such as TARB, where the impacts of fragmentation on environmental services (crop pollination, pest control, erosion and silting of water bodies, etc.) are felt more directly should be a priority (Haddad et al., 2015).

As recorded by Castro et al. (2020) in the Xingu Endemism Area, the conflict of interests and the potential for exploiting varied natural resources (water, forests, soils, non-metallic minerals) shaped the occupation and transformation of the Tarumã-Açu basin landscape. The impacts of forest cover loss are possibly aggravated by reducing fragment size, creating edges and reducing connectivity (structural and functional). In addition, there is a lack of governance, integrated policies and management instruments, such as the watershed plan and the CUs management plans.

It was seen that the creation of individual conservation units did not bring the expected collective benefit to TARB. Thus, the planning and use of network strategies can present better results for Tarumã-Açu basin landscape conservation/restoration. As proposed by Haddad et al. (2015) and Castro et al. (2020), these strategies can initially focus on prioritizing the protection of those fragments with high connectivity potential (IIC and PC), which are not protected; the enrichment of buffer zones of small fragments with fast growing native species in the low course, due to the urban use already consolidated in this region; and effective land use planning.

Whatever the plan, its implementation and effectiveness will depend, above all, on the articulation capacity of the basin committee, responsible for promoting dialogue between the various stakeholders, trying to balance management, socioeconomic development and natural biophysical aspects of the basin's landscape, as stated Lima and Garcez (2017) and Trindade and Scheibe (2019). These aspects are interdependent and mutually influential when it comes to the planning and management of urban and periurban watersheds, and, although complex, this integration must start from the assumption of the forest-water relationship transversality (Diniz et al., 2020).

\section{Conclusions}

The TARB is very fragmented with a higher degree of forest degradation in the low basin, including protected areas except the Adolpho Ducke Forest Reserve, although it still has good vegetation conservation potential. The headwater region, in turn, has the largest size and core area amount fragments, in addition to high structural and functional connectivity, which are fundamental for the natural resources and basin's landscape sustainability, however it is not under protection.

The small fragments of the low basin, despite the greater vulnerability to edge effects and anthropogenic pressures, and reduced potential for functional connectivity, present physical isolation values close to landscape mean value, indicating their potential role as a link between larger patches, functioning as connection elements and requiring equal attention from watershed and UCs managers. In the urban context, well-planned and executed landscape measures, using fast-growing native species, can help in the process of maintaining TARB's ecosystem services.

The present characterization of structural and functional patterns of the Tarumã-Açu basin landscape offers important subsidies to elaboration of the management plan and to definition of the forest remnants conservation and restoration strategies, indicating priority areas for the implementation of these actions from production of unprecedented data on forest fragmentation in the TARB's context. The management of the basin's natural landscape needs to envision mitigating the impacts of human transformations, which, in this context, are numerous (and inevitable, from the perspective of socioeconomic development). This should help to support the eco-hydrological dynamics responsible for water resources, soils, biodiversity sustainability and, therefore, for the very economic and social activities that occur into the TARB.

\section{Contribution of authors:}

Costa, J.S.: Conceptualization, Methodology, Formal analysis, Data curation, Writing — original draft, Writing — review and editing; Rodrigues, L.S.: Formal analysis, Data curation, Writing - review; Silva, A.G.C.: Formal analysis, Data curation, Writing - review; Reis, T.C.: Formal analysis, Data curation, Writing — review; Melo, M.G.G.: Supervision, Validation, Writing - review; Liberato, M.A.R.: Supervision, Validation, Writing — review. 


\section{References}

Amazonas. 2020. Secretaria de Estado do Meio Ambiente. Plano Estadual de Recursos Hídricos do Estado do Amazonas: Resumo Executivo. SEMA, Manaus.

Andrade, A.S.; Ribeiro, S.C.A.; Pereira, B.W.F.; Brandão, V.V.P., 2020. Fragmentação da vegetação da bacia hidrográfica do Rio Marapanim, nordeste do Pará. Ciência Florestal, v. 30, (2), 406-420. https://doi. org/10.5902/1980509835074

Antongiovanni, M.; Metzger, J.P., 2005. Influence of matrix habitats on the occurrence of insectivorous bird species in Amazonian forest fragments. Biological Conservation, v. 122, (3), 441-451. https://doi.org/10.1016/j. biocon.2004.09.005

Antonio, I.C., 2017. Índices climáticos e caracterização climática no entorno de Manaus. Revista Brasileira de Geografia Física, v. 10, (4), 1120-1133. https:// doi.org/10.26848/rbgf.v10.4.p1120-1133

Aragón, G.; Abuja, L.; Belinchón, R.; Martínez, I., 2015. Edge types determines the intensity of forest edge effect on epiphytic communities. European Journal of Forest Research, v. 134, 443-451. http://dx.doi.org/10.1007/s10342-0150863-5

Baranyi, G.B.; Saura, S.; Podani, J., Jordán, F., 2011. Contribution of habitat patches to network connectivity: redundancy and uniqueness of topological indices. Ecological Indicators, v. 11, (5), 1301-1310. https://doi.org/10.1016/j. ecolind.2011.02.003

Barber, C.P.; Cochrane, M.A.; Souza Júnior, C.M.; Laurance, W.F., 2014. Roads, deforestation, and the mitigating effect of protected areas in the Amazon. Biological Conservation, v. 177, 203-209. https://doi.org/10.1016/j. biocon.2014.07.004

Biggs, R.; Schlüter, M.; Schoon, M.L., 2015. Principles for building resilience: sustaining ecosystem services in social-ecological systems. Cambridge University Press, Cambridge. https://doi.org/10.1017/CBO9781316014240

Brasil. 1997. Lei no 9.433, de 8 de janeiro de 1997. Política Nacional de Recursos Hídricos.: Presidência da República, Brasília (Accessed December 17, 2018) at: http://planalto.gov.br/ccivil_03/LEIS/L9433.htm

Brasil. Ministério do Meio Ambiente. World Resources Institute. 2017. Potencial de Regeneração Natural da Vegetação no Brasil. Plano Nacional de Recuperação da Vegetação Nativa. Ministério do Meio Ambiente, Brasília.

Briant, G.; Gond, V.; Laurance, S.G., 2010. Habitat fragmentation and the desiccation of forest canopies: a case study from eastern Amazonia. Biological Conservation, v. 143, (11), 2763-2769. https://doi.org/10.1016/j. biocon.2010.07.024

Cabral, A.I.R.; Costa, F.L., 2017. Land cover changes and landscape patterns dynamics in Senegal and Guinea Bissau borderland. Applied Geography, v. 82, 115-128. https://doi.org/10.1016/j.apgeog.2017.03.010

Castro, R.B.; Pereira, J.L.G.; Saturnino, R.; Monteiro, P.S.D.; Albernaz, A.L.K.M., 2020. Identification of priority areas for landscape connectivity maintenance in the Xingu Area of Endemism in Brazilian Amazonia. Acta Amazonica, v. 50, (1), 68-79. https://doi.org/10.1590/1809-4392201903080

Cavalcante, J.C.; Souza Filho, J.S.; Vale, R.S.; Costa, D.C.T., 2020. Análise multicriterial na definição de áreas prioritárias para a conservação florestal em São Félix do Xingu - PA. Revista Brasileira de Geografia Física, v. 13, (1), 167181. https://doi.org/10.26848/rbgf.v13.1.p167-181

Chazdon, R.L.; Brancalion, P.H.S.; Lamb, D.; Laestadius, L.; Calmon, M.; Kumar, C., 2017. A policy-driven knowledge agenda for global forest and landscape restoration. Conservation Letters, v. 10, (1), 125-132. https://doi. org/10.1111/conl.12220
Costa, E.B.S.; Silva, C.L.; Silva, M.L., 2013. Caracterização física de bacias hidrográficas na região de Manaus - AM. Caminhos de Geografia (online), v. 14, (46), p. 93-100.

Costa, J.R.; Soares, J.E.C.; Mota, A.M.; Coral, S.T., 2012. Ações integradas em busca da sustentabilidade no Assentamento Tarumã-Mirim, zona rural de Manaus (AM). Revista Brasileira de Agroecologia, v. 7, (1), 14-24.

Crouzeilles, R.; Curran, M., 2016. Which landscape size best predicts the influence of forest cover on restoration success? A global meta-analysis on the scale of effect. Journal of Applied Ecology, v. 53, (2), 440-448. http://doi. org/10.1111/1365-2664.12590

Diniz, F.R.; Vieira Filho, L.; Montezuma, R., 2020. The Capibaribe Park Project, Recife: using the river to reinvente the city. Revista Brasileira de Ciências Ambientais, v. 55, (3), 331-353. http://dx.doi.org/10.5327/z2176-947820200619

Duarte, M.L.; Brito, W.B.M.; Silva, T.A.; Castro, A.L., 2020. Padrões e causas do desmatamento no Baixo Acre, região oeste da Amazônia Brasileira. Journal of Environmental Analysis and Progress, v. 5, (1), 117-127. https://doi. org/10.24221/jeap.5.1.2020.2790.117-127

Empresa Brasileira de Pesquisa Agropecuária (EMBRAPA). 2003. Diagnóstico Sócio-Ambiental do Projeto de Assentamento Tarumã Mirim. INCRA/ SEPROR, Manaus.

Farias, M.H.C.S.; Beltrão, N.E.S.; Cordeiro, Y.E.M.; Santos, C.A., 2018. Impacto of rural settlements on the deforestation of the Amazon. Mercator, v. 17, (5), 1-20. https://doi.org/10.4215/rm2018.e17009

Fearnside, P.M., 2016. Tropical dams: to build or not to build? Science, v. 351, (6272), 456-457. http://dx.doi.org/10.1126/science.351.6272.456-b

García-Márquez, J.R.; Krueger, T.; Páez, C.P.; Ruíz-Agudelo, C.A.; Bejarano, P.; Muto, T.; Arjona, F., 2017. Effectiveness of conservation areas for protecting biodiversity and ecosystem services: a multi-criteria approach. International Journal of Biodiversity Science, Ecosystem Services \& Management, v. 13, (1), 1-13. https://doi.org/10.1080/21513732.2016.1200672

Gloor, M.; Brienen, R.J.W.; Galbraith, D.; Feldpausch, T.R.; Schöngart, J.; Guyot, J.L.; Espinoza, J.C.; Lloyd, J.; Phillips, O.L., 2013. Intensification of the Amazon hydrological cycle over the last two decades. Geophysical Research Letters, v. 40, (9), 1729-1733. https://doi.org/10.1002/grl.50377

Gomes, M.M.; Vitória, C.F.; Silva, E.R.; Almeida, J.R., 2019. Avaliação de impactos ambientais da duplicação da BR $101 \mathrm{RJ} /$ Norte, trecho compreendido entre o km 144,2 e 190,3. Revista Internacional de Ciências, v. 9, (1), 22-34. https://doi.org/10.12957/ric.2019.35980

Gross, J.L.; Yellen, J.; Anderson, M., 2019. Graph Theory and its applications. 3. ed. CRC Press, Boca Raton.

Haddad, N.M.; Brudvig, L.A.; Clobert, J.; Davies, K.F.; Gonzalez, A.; Holt, R.D.; Lovejoy, T.E.; Sexton, J.O.; Austin, M.P.; Collins, C.D.; Cook, W.M.; Damschen, E.I.; Ewers, R.M.; Foster, B.L.; Clinton, N.J.; King, A.J.; Laurance, W.F.; Levey, D.J.; Margules, C.R.; Melbourne, B.A.; Nicholls, A.O.; Orrock, J.L.; Song, D.X.; Townshend, J.R., 2015. Habitat fragmentation and its lasting impact on Earth's ecosystems. Science Advances, v. 1, (2), e1500052. http://dx.doi.org/10.1126/ sciadv.1500052

Hansen, M.C.; Wang, L.; Song, X.P.; Tyukavina, A.; Turubanova, S.; Potapov, P.V.; Stehman, S.V., 2020. The fate of tropical forest fragments. Science Advances, v. 6, (11), eaax8574. http://dx.doi.org/10.1126/sciadv. aax 8574

Instituto Brasileiro de Geografia e Estatística (IBGE). 2013. Manual Técnico de Uso da Terra. 3. ed. IBGE, Rio de Janeiro. 
Jesus, E.N.; Ferreira, R.A.; Aragão, A.G.; Santos, T.I.S.; Rocha, S.L., 2015. Estrutura dos fragmentos florestais da Bacia Hidrográfica do Rio Poxim - SE, como subsídio à restauração ecológica. Revista Árvore, v. 39, (3), 467-474. https://doi.org/10.1590/0100-67622015000300007

Jiménez-Muñoz, J.C.; Mattar, C.; Barichivich, J.; Santamaría-Artigas, A.; Takahashi, K.; Malhi, Y.; Sobrino, J.A.; Van Der Schrier, G., 2016. Recordbreaking warming and extreme drought in the Amazon rainforest during the course of El Niño 2015-2016. Scientific Reports, v. 6, e33130. http://dx.doi. org/10.1038/srep33130

Khanna, J.; Medvigy, D.; Fueglistaler, S.; Walko, R., 2017. Regional dry-season climate changes due to three decades of Amazonian deforestation. Nature Climate Change, v. 7, 200-204. http://dx.doi.org/10.1038/nclimate3226

Landis, J.R.; Koch, G.G., 1977. The measurement of observer agreement for categorical data. Biometrics, v. 33, (1), 159-174. http://dx.doi. org/10.2307/2529310

Laurance, W.F.; Camargo, J.L.C.; Fearnside, P.M.; Lovejoy, T.E.; Williamson, B.; Mesquita, R.C.G.; Meyer, C.F..; Bobrowiec, P.E.D.; Laurance, S.G.W., 2018. An Amazonian rainforest and its fragments as a laboratory of global change. Biological Reviews, v. 93, (1), 223-247. http://dx.doi.org/10.1111/brv.12343

Laurance, W.F.; Camargo, J.L.C.; Luizão, R.C.C.; Laurance, S.G.; Pimm, S.L.; Bruna, E.M.; Stouffer, P.C.; Williamson, B.; Benítez-Malvido, J.; Vasconcelos, H.L.; Van Houtan, K.S.; Zartman, C.E.; Boyle, S.A.; Didham, R.K.; Andrade, A.; Lovejoy, T.E., 2011. The fate of Amazonian forest fragments: A 32-year investigation. Biological Conservation, v. 144, (1), 56-67. http://dx.doi. org/10.1016/j.biocon.2010.09.021

Leite, M.S.; Tambosi, L.R.; Romitelli, I.; Metzger, J.P., 2013. Landscape ecology perspective in restoration projects for biodiversity conservation: a review. Natureza \& Conservação, v. 11, (2), 108-118. http://dx.doi.org/10.4322/ natcon.2013.019

Lima, S.M.; Garcez, D.S., 2017. Áreas verdes públicas urbanas e sua relação com a melhoria da qualidade de vida: um estudo de caso em um parque ecológico urbano na cidade de Fortaleza (Ceará, Brasil). Revista Brasileira de Ciências Ambientais, (43), 140-151. https://doi.org/10.5327/Z2176947820170126

Lisboa, L.S.; Almeida, A.S.; Lameira, W.J., 2019. Análise temporal da fragmentação florestal no leste da Amazônia Legal. Novos Cadernos NAEA, v. 22, (3), 141-156. http://dx.doi.org/10.5801/ncn.v22i3.6571

Maeda, E.E.; Kim, H.; Aragão, L.E.O.C.; Famiglietti, J.S.; Oki, T., 2015. Disruption of hydroecological equillibrium in southwest Amazon mediated by drought. Geophysical Research Letters, v. 42, (18), 7546-7553. http://dx.doi. org/10.1002/2015GL065252

Magnuszewski, P.; Ostasiewicz, K.; Chazdon, R.; Salk, C.; Pajak, M.; Sendzimir, J.; Andersson, K., 2015. Resilience and alternative stable states of tropical forest landscapes under shifting cultivation regimes. PLoS One, v. 10, (9), e0137497. https://doi.org/10.1371/journal.pone.0137497

Marengo, J.A.; Tomasella, J.; Soares, W.R.; Alves. L.M.; Nobre, C.A., 2011. Extreme climatic events in the Amazon basin. Theoretical and Applied Climatology, v. 107, (1-2), 73-85.

Nobre, C.A.; Sampaio, G.; Borma, L.S.; Castilla-Rubio, J.C.; Silva, J.S.; Cardoso, M., 2016. Land-use and climate change risk in the Amazon and the need of a novel sustainable development paradigm. Proceedings of the National Academy of Sciences of the USA, v. 113, (39), p. 10759-10768. http://dx.doi. org/10.1073/pnas.1605516113

Numata, I.; Cochrane, M.A., 2012. Forest fragmentation and its potential implications in the Brazilian Amazon between 2001 and 2010. Open Journal of Forestry, v. 2, (4), 265-271. http://dx.doi.org/10.4236/ojf.2012.24033
Odum, E.P.; Barret, G.W., 2008. Fundamentos de Ecologia. 5. ed. Cengage Learning, São Paulo.

Oliveira, P.S.; Moreira, A.A.; Nery, C.V.M.; Melo, A.A.M., 2015. Microcorredores ecológicos no entorno do Parque Estadual da Lapa Grande. Caminhos da Geografia, v. 16, (53), 189-200.

Pereira, V.H.C.; Cestaro, L.A., 2016. Corredores ecológicos no Brasil: avaliação sobre os principais critérios utilizados para definição de áreas potenciais. Caminhos da Geografia, v. 17, (58), 16-33. https://doi.org/10.14393/ RCG175802

Programa de Desenvolvimento Sustentável da Produção Familiar Rural da Amazônia (PROAMBIENTE). 2002. Diagnóstico rápido e participativo do polo pioneiro no Amazonas: Projeto de Assentamento Tarumã-Mirim. PROAMBIENTE, Manaus.

Radford, J.Q.; Bennett, A.F., 2007. The relative importance of landscape properties for woodland birds in agricultural environments. Journal of Applied Ecology, v. 44, (4), 737-747. https://doi.org/10.1111/j.1365-2664.2007.01327.x

Ramos, A.P.M.; Marcato Junior, J.; Decanini, M.M.S.; Pugliesi, E.A.; Oliveira, R.F.; Paranhos Filho, A.C., 2016. Avaliação qualitativa e quantitativa de métodos de classificação de dados para o mapeamento coroplético. Revista Brasileira de Cartografia, Rio de Janeiro, v. 68, (3), 609-629

Rex, F.E.; Corte, A.P.D.; Kazama, V.S.; Sanquetta, C.R., 2018. Análise métrica da cobertura florestal da bacia hidrográfica do Rio Pequeno - PR. BIOFIX Scientific Journal, v. 3, (1), 184-192. http://dx.doi.org/10.5380/biofix.v3i1.58382

Ribeiro, H.V.; Galvanin, E.A.S.; Paiva, M.M., 2017. Análise das pressões antrópicas na bacia Paraguai/Jauquara - Mato Grosso. Ciência e Natura, v. 39, (2), 378-389. https://doi.org/10.5902/2179460X26090

Rocha, J.C.; Peterson, G.; Bodin, Ö.; Levin, S., 2018. Cascading regime shifts within and across scales. Science, v. 362, (6421), 1379-1383. https://doi. org $/ 10.1126 /$ science.aat 7850

Rocha, N.C.V.; Lima, A.M.M., 2020. A sustentabilidade hídrica na bacia do rio Guamá, Amazônia Oriental/Brasil. Sociedade \& Natureza, v. 32, 141-160. https://doi.org/10.14393/SN-v32-2020-45694

Rodríguez, J.M.M.; Silva, E.V.; Cavalcanti, A.P.B. (Eds.). 2017. Geoecologia das paisagens: uma visão geossistêmica da análise ambiental. 5. ed. Edições UFC, Fortaleza.

Rodríguez, J.M.M.; Silva, E.V.; Figueiró, A.S., 2019. La geoecologia de los paisajes como base teórico-metodológica para incorporar la dimensión tecnológica a la temática ambiental. Desenvolvimento e Meio Ambiente, v. 51, p. 84-103. http://dx.doi.org/10.5380/dma.v51i0.65410

Rudnick, D.A.; Ryan, S.J.; Beier, P.; Cushman, S.A.; Dieffenbach, F.; Epps, C.W.; Gerber, L.R.; Hartter, J.; Jenness, J.S.; Kintsch, J.; Merenlender, A.M.; Perkl, R.M.; Preziosi, D.V.; Trombulak, S.C., 2012. The role of landscape connectivity in planning and implementing conservation and restoration priorities. Issues in Ecology, 16, 1-20.

Ruiz-Agudelo, C.A.; Mazzeo, N.; Díaz, I.; Barral, M.P.; Piñeiro, G.; Gadino, I.; Roche, I.; Acuña-Posada, R.J., 2020. Land use planning in the Amazon basin: challenges from resilience thinking. Ecology and Society, v. 25, (1), 8. https:// doi.org/10.5751/ES-11352-250108

Rusca, G.G.; Moraes, M.C.P.; Valente, R.A.; Piña-Rodrigues, F.C.M., 2017. Análise espacial dos fragmentos florestais no entrono de uma Unidade de Conservação de Proteção Integral. Revista Brasileira de Ciências Ambientais, (44), p. 85-94. https://doi.org/10.5327/Z2176-947820170146

Santos, F.A.A.; Rocha, E.J.P.; Santos, J.S., 2019. Dinâmica da paisagem e seus impactos ambientais na Amazônia. Revista Brasileira de Geografia Física, v. 12, (5), 1794-1815. https://doi.org/10.26848/rbgf.v12.5.p1794-1815 
Saura, S.; Bodin, Ö.; Fortin, M.J., 2014. Stepping stone are crucial for species' long-distance dispersal and range expansion through habitat networks. Journal of Applied Ecology, v. 51, (1), 171-182. https://doi.org/10.1111/13652664.12179

Saura, S.; Estreguil, C.; Mouton, C.; Rodríguez-Freire, M., 2011. Network analysis to assess landscape connectivity trends: application to European forests (1990-2000). Ecological Indicators, v. 11, (2), 407-416. https://doi. org/10.1016/j.ecolind.2010.06.011

Saura, S.; Torné, J., 2012. Conefor 2.6 user manual. Universidad Politécnica de Madrid, Madrid.

Scheffer, M.; Bolhuis, J.E.; Borsboom, D.; Buchman, T.G.; Gijzel, S.M.; Goulson, D.; Kammenga, J.E.; Kemp, B.; Van De Leemput, I.A.; Levin, S.; Martin, C.M.; Melis, R.J.F.; Van Nes, E.H.; Romero, L.M.; Rikkert, M.G.M.O., 2018. Quantifying resilience of humans and other animals. Proceedings of the National Academy of Sciences of the USA, v. 115, (47), 11883-11890. https:// doi.org/10.1073/pnas.1810630115

Scholten, T.; Hartmann, T.; Spit, T., 2020. The spatial component of integrative water resources management: differentiating integration of land and water governance. International Journal of Water Resources Development, v. 36, (5), 800-817. https://doi.org/10.1080/07900627.2019.1566055

Serrão, E.A.O.; Silva, M.T.; Sousa, F.A.S.; Lima, A.M.M.; Santos, C.A.; Ataide, L.C.P.; Silva, V.P.R., 2019. Four decades of hydrological process simulation of the Itacaiúnas River Watershed, Southeast Amazon. Bulletin of Geodetic Sciences, v. 25, (3), e20190018. http://dx.doi.org/10.1590/s198221702019000300018

Sheil, D., 2018. Forests, atmospheric water and an uncertain future: the new biology of the global water cycle. Forest Ecosystems, v. 5, 19. https://doi. org/10.1186/s40663-018-0138-y

Silva, K.C.L.; Carvalho, W.V.; Vieira, I.C.G.; Costa, D.C.T., 2020. Usos da terra e potencial de regeneração natural da vegetação nativa na bacia do rio Apeú, Castanhal, Pará. Revista de Ciências Agrárias, v. 63, 1-9. http://dx.doi. org/10.22491/rca.2020.3176

Siqueira, L.F., 2019. Estudo hidrológico do efeito de barramento hidráulico no rio Tarumã-Açu, Manaus-AM. 2019. Dissertation, Mestrado em Clima e Ambiente, Instituto Nacional de Pesquisas da Amazônia; Universidade do Estado do Amazonas, Manaus.

Sonter, L.J.; Herrera, D.; Barrett, D.J.; Galford, G.L.; Moran, C.J.; Soares-Filho, B.S., 2017. Mining drives extensive deforestation in the Brazilian Amazon. Nature Communications, v. 8, 1013. https://doi.org/10.1038/s41467-01700557-w

Spera, S.A.; Galford, G.L.; Coe, M.T.; Macedo, M.N.; Mustard, J.F., 2016. Landuse change affects water recycling in Brazil's last agricultural frontier. Global Change Biology, v. 22, (10), 3405-3413. http://dx.doi.org/10.1111/gcb.13298

Stimson, R.J., 2017. Some challenges for regional science research. Investigaciones Regionales, (36), 11-34

Thiago, C.R.L.; Magalhães, I.A.L.; Santos, A.R., 2020. Identificação de fragmentos florestais potenciais para delimitação de corredores ecológicos na bacia hidrográfica do Rio Itapemirim, ES por meio técnicas de sensoriamento remoto. Revista Brasileira de Geografia Física, v. 13, (2), 595-612. https://doi. org/10.26848/rbgf.v13.2.p595-612

Trenberth, K.E., 2011. Changes in precipitation with climate change. Climate Research, v. 47, (1-2), 123-138. https://doi.org/10.3354/cr00953

Trindade, L.L.; Scheibe, L.F., 2019. Water management: constraints to and contributions of Brazilian watershed Management Committees. Ambiente \& Sociedade, v. 22, e02672. https://doi.org/10.1590/18094422asoc20160267r2vu201912ao

Trombeta, L.R.; Leal, A.C., 2016. Planejamento ambiental e geoecologia das paisagens: contribuições para a bacia hidrográfica do Córrego Guaiçarinha, município de Álvares Machado, São Paulo, Brasil. Revista Formação (online), v. 3, (23), 187-216. https://doi.org/10.33081/formacao.v3i23.4026

Wang, L.; Kaseke, K.F.; Seely, M.K., 2017. Effects of non-rainfall water inputs on ecosystem functions. WIREs Water, v, 4, (1), e1179. http://doi.org/10.1002/ wat2.1179

Ziólkowska, E.; Ostapowicz, K.; Radeloff, V.C.; Kuemmerle, T., 2014. Effects of different matrix representations and connectivity measures on habitat network assessments. Landscape Ecology, v. 29, 1551-1570. https://doi.org/10.1007/ s10980-014-0075-2 